\title{
Seasonal benthic organic matter mineralisation measured by oxygen uptake and denitrification along a transect of the inner and outer River Thames estuary, UK
}

\author{
M. Trimmer ${ }^{1}$, D. B. Nedwell ${ }^{1, *}$, D. B. Sivyer ${ }^{2}$, S. J. Malcolm ${ }^{2}$ \\ ${ }^{1}$ Department of Biological Sciences, University of Essex, Colchester CO4 3SQ, United Kingdom \\ ${ }^{2}$ Centre for Environment Fisheries and Aquaculture Sciences, Lowestoft NR33 OHT, United Kingdom
}

\begin{abstract}
Seasonal measurements of organic matter mineralisation by oxygen uptake and denitrification were carried out from July 1996 to March 1998 along a $200 \mathrm{~km}$ transect of the River Thames estuary, UK. There was a distinct gradient of decreasing rates of organic matter mineralisation seaward, which was related to the concentration of suspended solids and sedimentary organic carbon (C) at each site. There was clear seasonality and highest rates of oxygen uptake $\left(10056 \mu \mathrm{mol} \mathrm{O}_{2} \mathrm{~m}^{-2} \mathrm{~h}^{-1}\right)$ at the muddy sites, but lower rates and non-temperature-dependent oxygen uptake at the sandier sites. Denitrification, both that driven by nitrate from the overlying water $\left(D_{w}\right)$ and that coupled to nitrification in the sediment $\left(D_{n}\right)$, followed a similar trend to oxygen uptake, from negligible rates of approximately $1 \mu \mathrm{mol} \mathrm{N} \mathrm{m}{ }^{-2} \mathrm{~h}^{-1}$ for both $D_{\mathrm{w}}$ and $D_{\mathrm{n}}$ at the furthest offshore site, Site 12, to 11407 and $8209 \mu \mathrm{mol}$ $\mathrm{N} \mathrm{m}^{-2} \mathrm{~h}^{-1}$, respectively, at the inner muddy Site 1 . The Thames estuary is heterotrophic and a very efficient organic C filter, trapping and remineralising $77 \%$ of its organic $\mathrm{C}$ input. Attenuation of fluvial nitrate loads was regulated by freshwater flow. Minimal attenuation ( $3 \%$ ) occurred during peak flows (i.e. during periods of shortest freshwater flushing time) and $>100 \%$ attenuation during periods of lowest freshwater flow (longest flushing times). Including the sewage treatment works (STWs) nitrate load in this calculation reduced the degree of attenuation of the nitrate load to, on average, $11 \%$. Annual rates of $D_{w}$ and $D_{\mathrm{n}}$ for an inner area of $125 \mathrm{~km}^{2}$ were 112 and $85 \mathrm{Mmol} \mathrm{N} \mathrm{yr}^{-1}$, respectively, with a total rate of $196 \mathrm{Mmol} \mathrm{N} \mathrm{yr}^{-1}$ (2744 $\mathrm{t}$ ), which was equivalent to $9 \%$ of the total dissolved inorganic nitrogen (DIN) load for 1995-96. A mean denitrification rate $\left(D_{\mathrm{w}}\right)$ of $0.64 \mathrm{~mol} \mathrm{~N} \mathrm{~m}^{-2} \mathrm{yr}^{-1}$, based on measurements in 4 east coast estuaries, was used to estimate a total rate of denitrification for the entire area of UK east coast estuaries. The total rate of $0.81 \mathrm{Gmol} \mathrm{N} \mathrm{yr}^{-1}$ represented $16 \%$ attenuation of the total fluvial discharge of nitrate $\left(-6 \mathrm{Gmol} \mathrm{N} \mathrm{yr}^{-1}\right)$ to the UK's east coast estuaries (1995-96) and hence a $16 \%$ reduction in the UK nitrate load to the North Sea.
\end{abstract}

KEY WORDS: Organic mineralisation · Oxygen uptake · Denitrification · Nutrient attenuation

\section{INTRODUCTION}

Estuaries are the major conduits between land and sea, through which flow the loads of soluble and particulate materials derived from the catchment area of each estuary. These loads may be derived from both leaching and run-off from the land and from atmospheric deposition within the catchment, each of which

•Corresponding author. E-mail: nedwd@essex.ac.uk may have anthropogenic components. Estuaries act as traps for both particulate and dissolved organic loads, as well as mineral particles. Settlement of organic matter in turn stimulates benthic respiration and a remineralisation of organic material. Oxygen is rapidly depleted with depth in surface sediments and anoxic mineralisation proceeds via alternative electron acceptors. In nutrient-enriched estuaries nitrate is often abundant and may be respired and in turn lost as $\mathrm{N}_{2}$ through denitrification (Nedwell 1975, Seitzinger et al. 1980, Billen et al. 1985, Law et al. 1991, Nielsen et al. 
1995, Nixon et al. 1996, Ogilvie et al. 1997, Trimmer et al. 1998).

Studies on benthic mineralisation in estuarine and coastal sediments have tended to be either spatially or temporally restricted (see Heip et al. 1995). Although both Kelley et al. (1990) and Middelburg et al. (1996) demonstrated gradients of decreasing mineralisation rates along estuaries, others have shown little variation between sediment sites (Hargrave \& Philips 1981, Jørgensen \& Sørensen 1985, Cammen 1991, Trimmer et al. 1998). Nowicki et al. (1997) reported denitrification data along an extensive gradient from Boston Harbour and Massachusetts Bay and did, at least for denitrification, show a clear relationship between sedimentary organic content and rates of mineralisation. However, their study did not include measurements of oxygen uptake by the sediment. The aim of the present study was to provide a detailed assessment (spatially and temporally) of mineralisation rates via oxygen uptake and denitrification along an estuarine and coastal gradient and to then use this data to assess the capacity of the Thames estuary as a biological filter for dissolved inorganic nitrogen (DIN) and organic C.

\section{MATERIALS AND METHODS}

Sample sites. The tidal Thames estuary covers an area of approximately $131 \mathrm{~km}^{2}$ (Fig. 1) and is the $100 \mathrm{~km}$ stretch of the River Thames between Teddington Weir (landward), where it is 100 to $200 \mathrm{~m}$ wide, and Southend Pier (seaward), where it is $7 \mathrm{~km}$ wide. It drains a catchment of $14000 \mathrm{~km}^{2}$ with a population of 12 million people. Spring and neap tides at Southend are 6 and $3 \mathrm{~m}$ respectively (Environment Agency unpubl. public access data, Environment Agency Data Centre, Twirton, UK].

This study of the Thames estuary (Fig. 1) was divided into an inshore and an offshore transect visited between July 1996 and March 1998. Initially, from July 1996 to February 1997, in the inner Thames, 6 sites were visited between Mucking Flats (Site 4) and

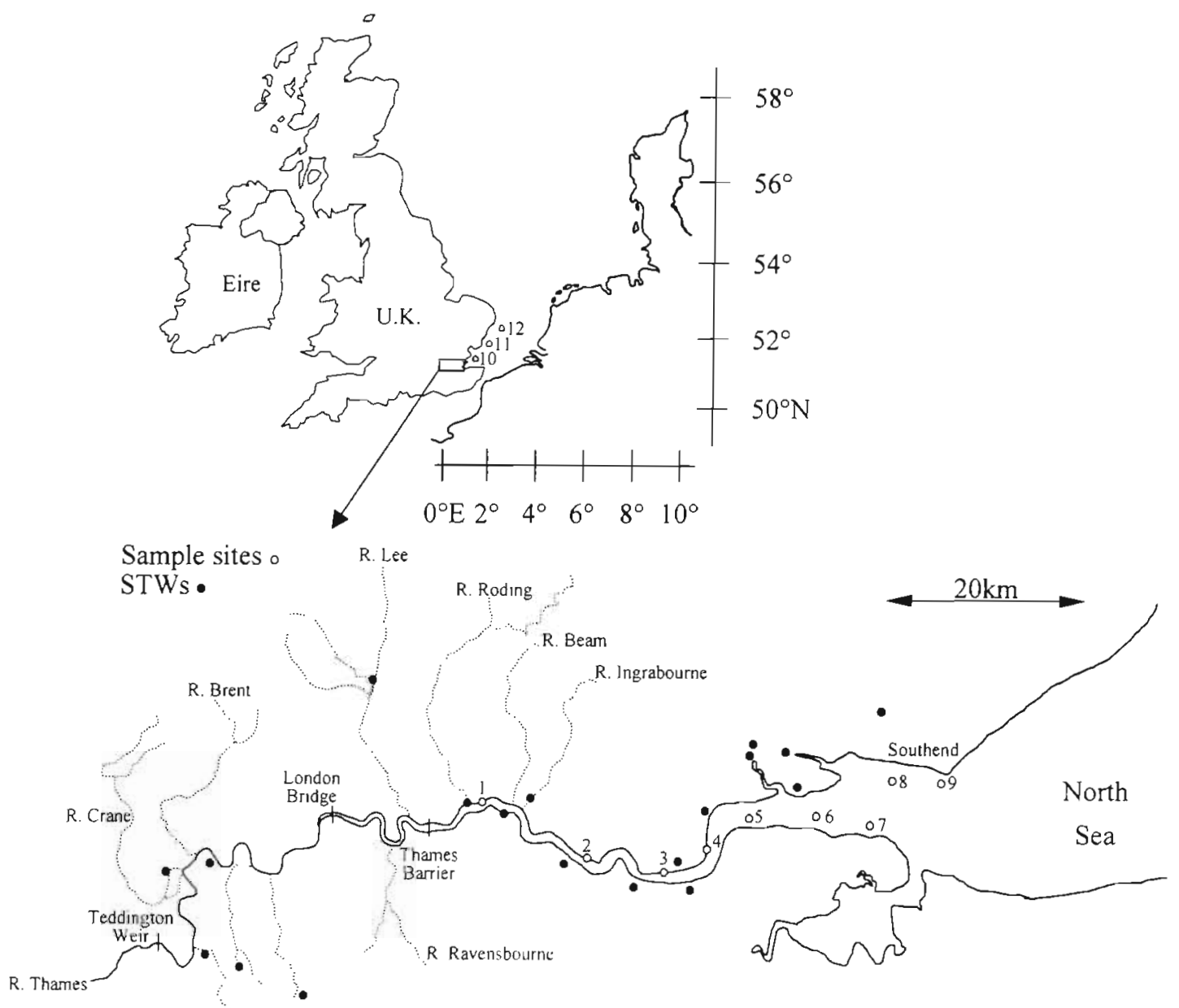

Fig. 1. Locations of the sample sites in both the inner and outer Thames transects. STWs: sewage treatment works 
Southend (Sites 8 and 9). This was followed by a 3 mo crossover period of visiting 9 sites, when the transect was extended upstream to Beckton (Site 1), where the major sewage treatment works (STWs) serving London discharge. Finally, from August 1997 to March 1998, 6 sites were visited between Beckton and Southend. The inshore transect was visited with a small (15 man) hovercraft 2 h after high-tide (water depth over sediments at high-tide $=2$ to $3 \mathrm{~m}$ ). Sample site positions were determined using a global positioning system (GPS) to within $-100 \mathrm{~m}^{2}$. The offshore transect extended from $16 \mathrm{~km}$ from Southend (Site 10, water depth at high-tide $=15 \mathrm{~m}$ ) to the furthest extent of the Thames plume, $122 \mathrm{~km}$ offshore (Site 12, water depth at high-tide $=45 \mathrm{~m}$ ) and was visited on board the RV 'Cirolina'. See Table 1 for locations and Table 2 for frequency and dates of visits.

Water column characteristics. Water samples (50 l) for core storage and analysis were collected by hand in plastic containers from each of the inner Thames sites. Bottom water samples (50 l) for storage of offshore sediment cores (see below) were collected using Niskin bottles mounted on a CTD rosette sampler. Subsamples of water $(20 \mathrm{ml})$ were taken from each inner estuary site for nutrient analysis, filtered $(0.2 \mu \mathrm{m}$ Minisart Plus ${ }^{\mathrm{TM}}$, Sartorius UK Ltd) and fixed with mercuric chloride solution $(200 \mu 1,0.2 \% \mathrm{w} / \mathrm{v}$; Kirkwood 1992). Additional water samples were taken for salinity $(200 \mathrm{ml})$ and chlorophyll $(500 \mathrm{ml})$ analyses. The water and air temperatures at each site were measured with a mercury thermometer and the air pressure for the survey day recorded. Similar samples were taken at the offshore sites directly from the Niskin bottles mounted on the CTD and analysed immediately. All nutrient analyses $\left(\mathrm{NO}_{3}{ }^{-}, \mathrm{NO}_{2}{ }^{-}, \mathrm{NH}_{4}{ }^{+}, \mathrm{SiO}_{3}\right.$ and $\mathrm{PO}_{4}{ }^{3-} ;$ Kirkwood 1996) were carried out using a continuous flow autoanalyser (Skalar, SA4000, De-Breada, The Netherlands). Salinity was measured using a salinometer (Autosal, Guildline, USA). Suspended loads were measured by filtering known volumes of water through preweighed glass fibre filters ( $5 \mathrm{~cm}$ diameter, $G F / F$, Whatman Ltd, UK), drying and reweighing. Chlorophyll was measured by filtering between 0.1 and $0.25 \mathrm{l}$ through GF/F glass fibre filters and extracting in neutralised $90 \%$ acetone for 24 h at $4^{\circ} \mathrm{C}$ in the dark. Measurements of extracted chlorophyll fluorescence (Tett 1987) were made (before and after acidification with $8 \%$ hydrochloric acid to distinguish phaeopigments) using a fluorometer (Turner Designs Model 10).

Sediment collection and storage. At each site in the inner Thames, sediment samples were collected by hand in approximately $50 \mathrm{~cm}$ of water. At the offshore sites, sediment samples were first collected using a NIOZ cylindrical box corer (31 cm inner diameter [i.d.], Netherlands Institute for Sea Research). The box corer collected 30 to $50 \mathrm{~cm}$ of sediment and 15 to $25 \mathrm{l}$ of site water; any cores that had drained were discarded and the box corer was redeployed. Three large sediment cores ( $\sim 30 \mathrm{~cm}$ deep) and overlying water (1 l) were collected to measure benthic oxygen uptake at each location using Perspex core tubes $(65 \mathrm{~cm}$ long $\times 8 \mathrm{~cm}$ i.d.) each sealed at the bottom with a silicon rubber bung. Smaller sediment cores $(\sim 10 \mathrm{~cm}$ deep) and overlying water $(\sim 100 \mathrm{ml})$ were collected to measure benthic denitrification at the same time using small perspex core tubes $(20 \mathrm{~cm}$ long $\times 3.4 \mathrm{~cm}$ i.d.), each sealed with a rubber bung. Cores from the inner sites were transported back to the laboratory usually within $3 \mathrm{~h}$. All cores were then stored open and submerged in aerated site water at the in situ temperature until required $k 2$ to $12 \mathrm{~h}$ ). The upper part of the inner Thames estuary suffers from a dissolved oxygen sag (Fig. 2). Therefore, storing the cores in aerated site water would have affected the in situ conditions and this would have been most dramatic at Sites 1 to 4 , where the mean in situ dissolved oxygen levels were between 55 and $70 \%$ of air saturation.

Sediment characteristics. Sediment cores $30 \mathrm{~cm} \times$ $6 \mathrm{~cm}$ i.d.) were taken at each site, to a depth of at least $15 \mathrm{~cm}$ and sealed at both ends with rubber bungs. Sediment porosity, particle size distribution, organic $C_{\text {, }}$ total nitrogen $(\mathrm{N})$ and chlorophyll concentrations were measured at $1 \mathrm{~cm}$ depths on extruded samples down to $10 \mathrm{~cm}$. Porosity was determined from the dry weights and wet weights of known volumes of sediment. Particle size distribution was measured by re-suspending each $1 \mathrm{~cm}$ slice in deionised water using an ultrasonic water bath and wet sieving through a range of stainless steel meshes $(2000,1000,500,250,125$ and $63 \mu \mathrm{m}$ pore sizes). Each fraction was then collected, re-dried and re-weighed. Particle size was expressed as a percentage of the total dry weight. Each sample for $\mathrm{C}$ and $\mathrm{N}$ analysis was homogenised with hydrochloric acid (5 $\mathrm{ml}, 1 \mathrm{M}$ ) to remove carbonate, and after re-drying subsamples (20 mg) were analysed for their organic C and $\mathrm{N}$ contents with a CHN analyser (model 2400, Perkin-Elmer Ltd, Norwalk, Connecticut, USA) calibrated with standard acetanilide $(71.09 \%$ C, $10.36 \%$ N). Sediment chlorophyll pigments were extracted $(2: 1$ sediment volume to acetone) and measured as described above. Sediment temperatures were measured with a mercury thermometer inserted into the surface sediment layer.

Sediment biological rate measurements. Oxygen uptake: The 3 large core tubes were capped and completely water-filled to exclude air bubbles. A mid-column water sample $(20 \mathrm{ml})$ was then drawn off into a gas-tight syringe, gently transferred to an Exetainer (12 ml Labco Ltd, High Wycombe, UK) and fixed for Winkler analysis of dissolved oxygen. The water col- 
umn in each tube was stirred with an induction motor driving a magnetic follower (Rank Brothers Ltd, Cambridge, UK) at $300 \mathrm{rpm}$ (Nedwell \& Trimmer 1996). The rates of benthic $\mathrm{O}_{2}$ uptake were measured using dissolved $\mathrm{O}_{2}$ electrodes (model 1302, Strathkelvin Ltd, Glasgow, UK) coupled to a 6 channel $\mathrm{O}_{2}$ meter (Essex Electronics Centre, Colchester, UK). The multi-channel $\mathrm{O}_{2}$ meter was connected to a computer (V.I.P computers, UK) with data analysis software (Notelog ${ }^{\text {, }}$ Garrat Consultants, Colchester, UK) which logged, displayed and analysed the data. The on-screen computer logging enabled the oxygen concentration in the water column to be continuously monitored and statistically analysed for linearity with respect to time. Significant rates of oxygen uptake $(\mathrm{p}<0.05)$ could usually be determined within 1 to $4 \mathrm{~h}$. Triplicate incubation chambers containing only site water $(500 \mathrm{ml})$, with no sediment present, were treated and incubated as above, to act as controls for water column remineralisation processes in the absence of sediment/water exchange.

Denitrification measured by isotope pairing: The 9 small sediment cores were used to measure denitrification rates using the ${ }^{15} \mathrm{NO}_{3}{ }^{-}$isotope pairing technique of Nielsen (1992). Six of the nine cores were spiked by addition of ${ }^{15} \mathrm{NO}_{3}{ }^{-}\left(10 \mathrm{mM} \mathrm{Na}{ }^{15} \mathrm{NO}_{3}{ }^{-}\right.$[99.3 atom\%, Europa, Crewe, UK]) into the overlying water and left to equilibrate for $0.5 \mathrm{~h}$ (Rysgaard et al. 1995). A prerequisite of the isotope pairing technique is a uniform mixing of the ${ }^{14} \mathrm{NO}_{3}{ }^{-}$and ${ }^{15} \mathrm{NO}_{3}{ }^{-}$isotopes throughout the denitrification zone (Nielsen 1992), which could have been a problem at the outer sites with a deeper oxic layer. In order to test for this we added ${ }^{15} \mathrm{NO}_{3}{ }^{-}$at a range of concentrations ( 5 to $40 \mu \mathrm{M}$ ), and if the calculated rates of coupled denitrification proved to be subsequently independent of the concentration of ${ }^{15} \mathrm{NO}_{3}{ }^{-}$ added, this was taken as good evidence for uniform mixing (Nielsen 1992, Nielsen \& Glud 1996). Once this had been proven cores were amended at the higher concentration of $40 \mu \mathrm{M}^{15} \mathrm{NO}_{3}{ }^{-}$to minimise the underestimation of denitrification (Nielsen \& Glud 1996). At the inner, higher nitrate sites enrichment of the $\mathrm{NO}_{3}$ pool was usually about $30 \%$ (Rysgaard et al. 1995).

Water samples ( $2 \mathrm{ml}$ ), collected from all core tubes to determine the initial ${ }^{14} \mathrm{NO}_{3}{ }^{-15} \mathrm{NO}_{3}$ ratio in the water overlying the treatment cores, were filtered and preserved prior to analyses (see above). The sediment in the 3 reference cores was then gently mixed into a slurry with the overlying water and a sample $(20 \mathrm{ml})$ carefully drawn off into an Exetainer (12 $\mathrm{ml}$ Labco Ltd, High Wycombe, UK) containing $\mathrm{ZnCl}_{2}$ solution (500 لر. $25 \% \mathrm{w} / \mathrm{v}$ ) and sealed. The ${ }^{15} \mathrm{NO}_{3}{ }^{-}$enriched cores were sealed and incubated in the dark at the in situ temperature, with gentle stirring $(\sim 60 \mathrm{rpm})$ of the water column for 2 to $6 \mathrm{~h}$. The on-screen data logging in the parallel oxygen uptake cores ensured that the con- centration of oxygen in the overlying water never fell below $80 \%$ of air saturation (see above). Following incubation, the ${ }^{15} \mathrm{NO}_{3}{ }^{-}$enriched cores were processed as the reference cores.

All the slurry samples were sent to the National Environmental Research Institute, Silkeborg, Denmark, to be analysed for abundance and concentration of ${ }^{28} \mathrm{~N}_{2},{ }^{29} \mathrm{~N}_{2}$ and ${ }^{30} \mathrm{~N}_{2}$ on a gas chromatograph coupled to a dual inlet isotope ratio mass spectrometer (Europa Instruments, Crewe, UK). Denitrification rates were calculated according to Nielsen (1992).

Calculation of freshwater flushing times, nutrient loads and attenuation. The Thames estuary was subdivided into 2 main sections according to the type of bathymetric data available $(H$. $R$. Wallingford Ltd, UK)-Section 1: Teddington Weir to Westminster Bridge and Section 2: Westminster Bridge to Southend Pier. Section 1 was subdivided into 25 sectors, each $1000 \mathrm{~m}$ long. The cross-sectional area of each sector (given at $0.5 \mathrm{~m}$ depths) was multiplied by its length $(1000 \mathrm{~m})$ to give the volume of water within each sector at mid-tide. Section 2 was subdivided into $75 \mathrm{sec}-$ tors, each $1000 \mathrm{~m}$ long. The width of the channel at $1.5 \mathrm{~m}$ intervals above or below chart datum (at midtide) was then used to construct a series of trapezia. The volume of water within each sector was calculated by multiplying the area of each trapezium (i.e. crosssectional areas) by the length of each box (i.e. $1000 \mathrm{~m}$ ) and summing the volume of all sectors.

Monthly (1992 to 1997) axial surveys of chlorinity (Cl) (Environment Agency unpubl. public access data) at discreet sampling sites along the estuary were used to assign a salinity $(S)$ value to each sector, using Knudsen's formula:

$$
S \%=0.030+(1.805 \times C I \%)
$$

The volume of freshwater within each sector was then calculated using:

$$
\begin{aligned}
\text { freshwater }\left(\mathrm{m}^{3}\right)= & \text { total volume of sector }\left(\mathrm{m}^{3}\right) \\
& \times\left[1-\left(S^{\circ} / S^{1}\right)\right]
\end{aligned}
$$

Where $S^{\circ}$ is the salinity value assigned to each sector and $S^{1}$ is the salinity of the offshore coastal water outside the estuary, in this case $35 \%$ or the southern North Sea.

Seasonal variations in freshwater flushing times for the Thames estuary were calculated by dividing the seasonal freshwater volumes by seasonal freshwater flows; taken as the sum of flows from the River Lee, River Roding and the River Thames flowing over Teddington Weir (Environment Agency unpubl. public access data)

Nutrient loads (monthly averages for 1995-96) for the Thames and all the UK east coast estuaries (The Wick in Scotland to The Medway in England) were calcu- 
lated by multiplying fluvial freshwater flows by nutrient concentrations (Harmonised Monitoring data, Department of the Environment, Transport and the Regions). Axial suspended solid and dissolved oxygen profiles (expressed as distance from London Bridge) along the Thames estuary (1993 to 1998) were provided by the Environment Agency (unpubl. public access data); sampling was usually within 2 to $3 \mathrm{~d}$ of our own sampling dates. The fluvial and STWs organic C loads to the Thames estuary are based on the most recent available data (Environment Agency unpubl. public access data) and are made up of average concentration data and average flow data for all data available to date from 11 rivers $181 \%$ being the Thames flowing into the estuary at Teddington), 16 STWs and 9 trade discharges (only 1 of which contributes more than $1 \%$ of the total organic $C$ budget).

\section{RESULTS}

\section{Water column characteristics}

Dissolved oxygen increased down the inner estuary (Fig. 2), with minimum saturation (with respect to air) either side of Site 1 (mean $55 \pm 4 \%$ $\mathrm{SE}, \mathrm{n}=14$ ) and maximum saturation at Site 9 $(92 \pm 2 \% \mathrm{SE}, \mathrm{n}=12)$. Dissolved oxygen increased at all sites during late spring (May 1997) and mid-winter (January 1998). Maximum nitrate concentrations were measured at the head of the transect at Site 1 (range 511 to $797 \mu \mathrm{M}$, mean $=611 \mu \mathrm{M})$, decreasing downstream to $0.6-9 \mu \mathrm{M}$ (mean $=4 \mu \mathrm{M}$ ) at Site 12 . Average chlorophyll concentrations did not vary significantly along the inner estuary; increasing from only $4 \mathrm{\mu g} \mathrm{l}^{-1}$ (range 1.3 to $7.3 \mu \mathrm{g} \mathrm{I}^{-1}$ ) at Site 1, to a peak of $8 \mathrm{\mu g} \mathrm{l}^{-1}$ (range 3.5 to $23 \mu \mathrm{g} \mathrm{l}^{-1}$ ) at Site 7 and then decreasing to $1.5 \mathrm{\mu g} \mathrm{l}^{-1}$ (range 0.6 to $2.9 \mathrm{\mu g} \mathrm{I}^{-1}$ ) at Site 9 . Maximum off-shore spring chlorophyll concentrations of 18.6 and $12.8 \mu \mathrm{g}^{-1}$ were measured at Sites 10 and 12 , respectively. Salinity increased from $2.1 \pm 0.2 \%$ ( $\mathrm{SE}, \mathrm{n}=45,5 \mathrm{yr}$ mean) at London Bridge to $31.7 \pm 0.7 \%$ (SE, $n=57,5$ yr mean) at Southend. The outer transect. sites (Sites 10 to 12 ) were essentially fully marine, with salinity varying (by a few \%o) from around $34.4 \%$ at Site 10 to around $35 \%$ at Site 12 .

Suspended loads initially increased down the estuary to $81 \pm 3.8 \mathrm{mg} \mathrm{l}^{-1}(\mathrm{SE}, \mathrm{n}=218,5 \mathrm{yr}$ mean) $18 \mathrm{~km}$ downstream from London Bridge, where both the major Beckton and Crossness STWs discharge (Fig. 3). Suspended loads then decreased further downstream until the broad high-tide turbidity maxi-

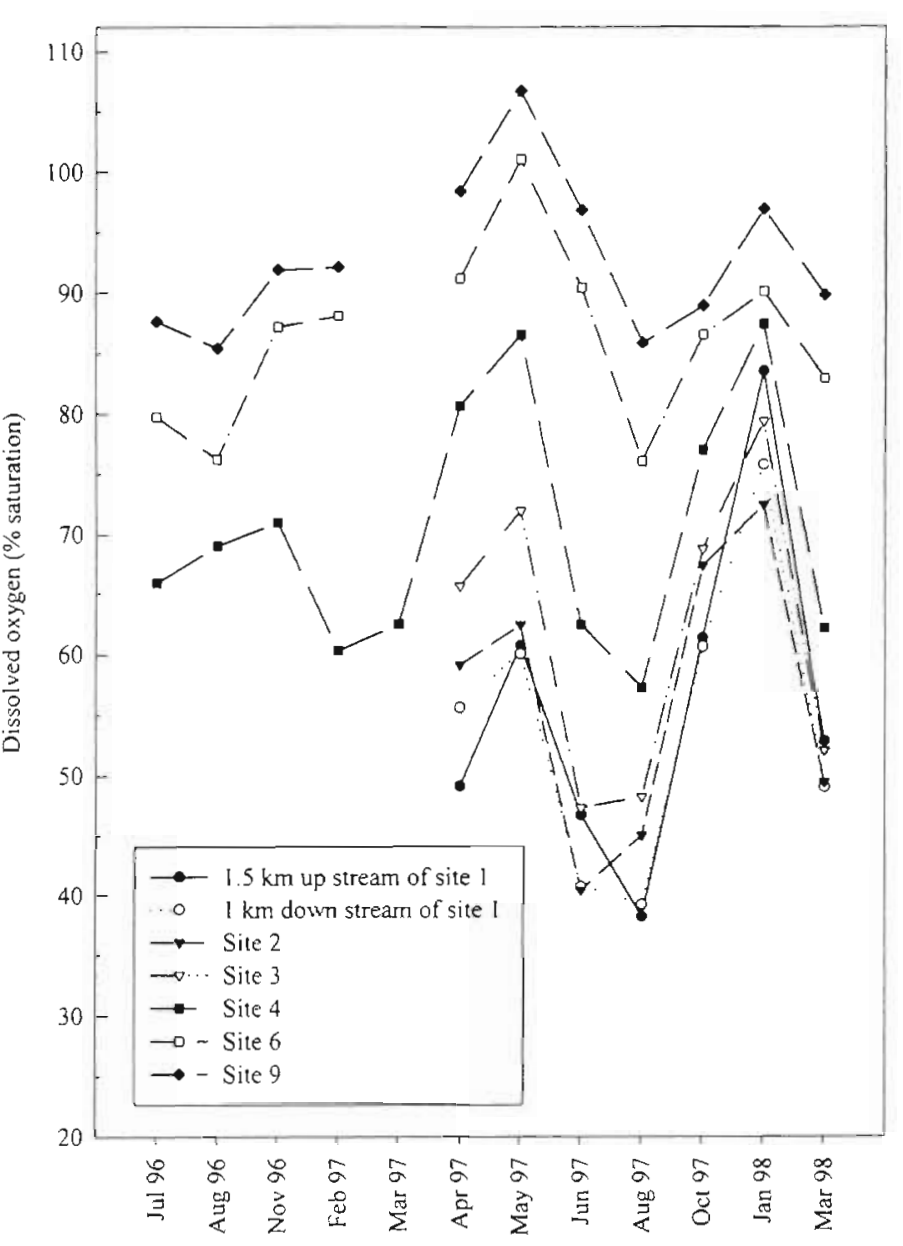

Fig. 2. Water column dissolved oxygen ( $\%$ of air saturation). Point samples collected by the Environment Agency (unpubl. public access data) within 2 to $3 \mathrm{~d}$ of this study's sampling date

mum was reached, between 35 and $53 \mathrm{~km}$ downstream around the Tilbury Basin mudflats, where suspended loads peaked at $90 \pm 5.6 \mathrm{mg} \mathrm{l}^{-1}$ (SE, $\mathrm{n}=219$, 5 yr mean). Suspended loads decreased again further seaward to their lowest values for the inner estuary at Southend of $28 \pm 2.9 \mathrm{mg} \mathrm{I}^{-t}$ ( $\mathrm{SE}, \mathrm{n}=58,5 \mathrm{yr}$ mean). There was then a third turbidity peak at Site 10 of $34 \pm 2.7 \mathrm{mg} \mathrm{l}^{-1}$ (SE, $\mathrm{n}=127$ ) followed by a steady decrease seaward out to Site $12\left(3.8 \mathrm{mg} \mathrm{l}^{-1} \pm 0.3 \mathrm{SE}\right.$, $\mathrm{n}=96$ ).

\section{Sediment characteristics}

From Site 1 seaward along the transect there was a general increase in particle size until, offshore, the sediments were dominated by fine and medium sands (Table 1). Porosity and organic $C$ were greatest at the muddy sites (Sites 1, 4 and 5), decreasing in proportion 
to each other $(p<0.05)$ seaward along the transect (Fig. 3). The lowest $\mathrm{C}: \mathrm{N}$ ratios were also recorded at the 3 muddy sites. Although a $\mathrm{C}: \mathrm{N}$ ratio of $12: 1$ was recorded at the offshore Site 12 , the percent total $N$ was probably below the limit of detection $(0.02 \%)$ and the value of the ratio therefore suspect.

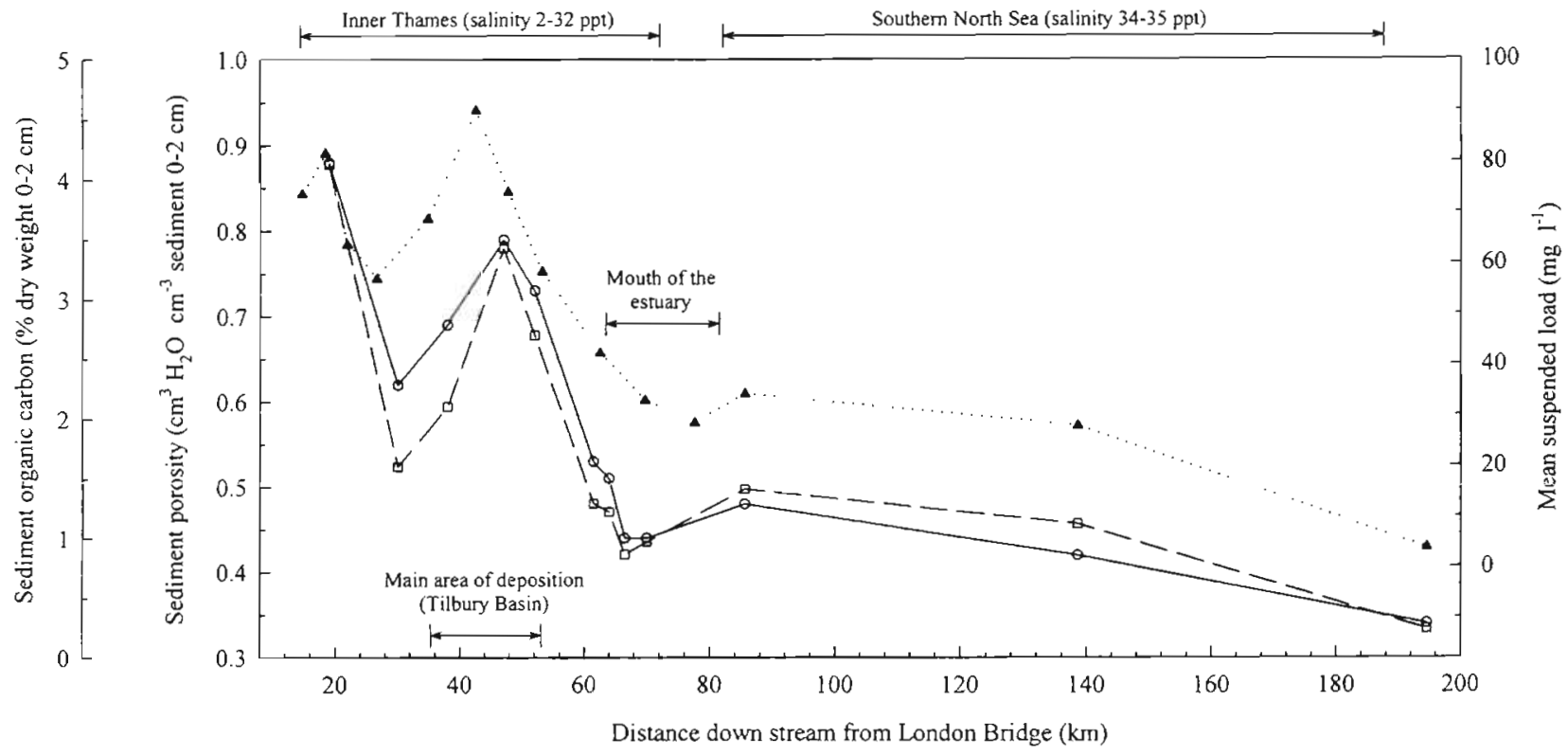

Fig. 3. Sediment porosity (O) and organic carbon ( $\square$ ); mean of all measurements for all sites from July 1996 to March 1998 . Suspended load ( $\mathbf{\Lambda}$ ); 18 to $80 \mathrm{~km}$ : 5 yr mean (Environment Agency unpubl. public access data), 80 to $200 \mathrm{~km}$ : mean of 6 surveys from July 1996 to April 1997

Table 1. Site locations and sediment characteristics for the 12 sites investigated on 6 occasions. Particle size measured once in May 1996 for inner Sites 4 to 10, July 1996 for outer Sites 1 to 3 and April 1997 for inner Sites 11 to 13

\begin{tabular}{|c|c|c|c|c|c|c|c|}
\hline \multirow[t]{2}{*}{ Site } & \multicolumn{2}{|c|}{ Location } & \multirow{2}{*}{$\begin{array}{l}\text { Particle size } \\
0-10 \mathrm{~cm} \\
(\geq 50 \% \mathrm{w} / \mathrm{w})\end{array}$} & \multirow{2}{*}{$\begin{array}{c}\text { Porosity } \\
0-2 \mathrm{~cm}^{\mathrm{c}} \\
\left(\mathrm{cm}^{3} \mathrm{H}_{2} \mathrm{O} \mathrm{\textrm {cm } ^ { - 3 }} \text { sed. }\right)\end{array}$} & \multirow{2}{*}{$\begin{array}{l}\text { Organic } \mathrm{C}^{\mathrm{d}} \\
0-2 \mathrm{~cm} \\
(\% \text { dry wt })\end{array}$} & \multirow{2}{*}{$\begin{array}{l}\text { Total } \mathrm{N}^{\mathrm{e}} \\
0-2 \mathrm{~cm} \\
(\% \text { dry } w t)\end{array}$} & \multirow{2}{*}{$\begin{array}{c}\text { C:N ratio } \\
0-2 \mathrm{~cm} \\
(\% \text { dry wt) }\end{array}$} \\
\hline & $N$ & $E$ & & & & & \\
\hline \multicolumn{8}{|l|}{ Inner } \\
\hline $1(\mathrm{TH} 11)$ & $51^{\circ} 31^{\prime} 07$ & $0^{\circ} 07^{\prime} 47$ & Silts/clays & 0.88 & 4.13 & 0.35 & $12: 1$ \\
\hline $2(\mathrm{TH} 12)$ & $51^{\circ} 27^{\prime} 76$ & $0^{\circ} 16^{\prime} 47$ & Very fine sands & 0.62 & 1.60 & 0.10 & $16: 1$ \\
\hline $3(\mathrm{TH} 13)$ & $51^{\circ} 27^{\prime} 09$ & $0^{\circ} 22^{\prime} 12$ & Very fine sands & 0.69 & 2.10 & 0.07 & $30: 1$ \\
\hline $4(\mathrm{TH} 9)$ & $51^{\circ} 28^{\prime} 80$ & $0^{\circ} 26^{\prime} 46$ & Silt/clays & 0.79 & 3.43 & 0.23 & $15: 1$ \\
\hline 5 (TH 5) & $51^{\circ} 29^{\prime} 20$ & $0^{\circ} 31^{\prime} 50$ & Silt/clays & 0.73 & 2.70 & 0.18 & $15: 1$ \\
\hline $6(\mathrm{TH} 10)$ & $51^{\circ} 29^{\prime} 49$ & $0^{\circ} 35^{\prime} 10$ & Very fine sands & 0.53 & 1.29 & 0.05 & $26: 1$ \\
\hline $7(\mathrm{TH} 4)$ & $51^{\circ} 29^{\prime} 47$ & $0^{\circ} 38^{\prime} 50$ & Fine sands & 0.51 & 1.22 & 0.05 & $24: 1$ \\
\hline $8(\mathrm{TH} 7)$ & $51^{\circ} 31^{\prime} 28$ & $0^{\circ} 40^{\prime} 83$ & Very fine-fine sands & 0.44 & 0.86 & $\leq 0.02$ & $43: 1$ \\
\hline $9(\mathrm{TH} 8)$ & $51^{\circ} 31^{\prime} 56$ & $0^{\circ} 44^{\prime} 44$ & Very fine sands & 0.44 & 0.97 & $\leq 0.02$ & $49: 1$ \\
\hline \multicolumn{8}{|l|}{ Outer } \\
\hline $10(\mathrm{TH} 1)$ & $51^{\circ} 30^{\prime} 80$ & $0^{\circ} 58^{\prime} 00$ & Very fine sands-silt/clays & 0.48 & 1.41 & 0.05 & $28: 1$ \\
\hline $11(\mathrm{TH} 2)$ & $51^{\circ} 48^{\prime} 00$ & $1^{\circ} 35^{\prime} 00$ & Fine sands & 0.42 & 1.12 & $\leq 0.02$ & $56: 1$ \\
\hline $12(\mathrm{TH} 3)$ & $52^{\circ} 00^{\prime} 00$ & $2^{\circ} 20^{\prime} 00$ & Medium sands & 0.34 & 0.24 & $\leq 0.02$ & $12: 1$ \\
\hline \multicolumn{8}{|c|}{$\begin{array}{l}\text { aSites have been renumbered sequentially for clarity but the original TH number is given for cross reference to other JoNuS } \\
\text { project papers }\end{array}$} \\
\hline \multicolumn{8}{|c|}{$\begin{array}{l}\text { "Wentworth classification (Tait 1981): medium sands, } 500 \text { to } 250 \mu \mathrm{m}_{\text {; }} \text { fine sands, } 250 \text { to } 125 \mu \mathrm{m} \text {; very fine sands, } 125 \text { to } \\
63 \mu \mathrm{m} \text {; silt/clays, }<63 \mu \mathrm{m}\end{array}$} \\
\hline \multicolumn{8}{|c|}{${ }^{\mathrm{C}} \mathrm{CV} 4 \%$} \\
\hline \multicolumn{8}{|l|}{${ }^{\mathrm{d}} \mathrm{CV} 14 \%$} \\
\hline${ }^{e} \mathrm{CV} 18 \%$ & & & & & & & \\
\hline
\end{tabular}


Chlorophyll concentrations in the surface 0 to $1 \mathrm{~cm}$ sediment layer showed no significant variation along the inner estuary (mean $27 \mathrm{mg} \mathrm{chl} \mathrm{a} \mathrm{m}^{-2}$ ) and showed no significant seasonal variation, apart from a small peak in May (mean $62 \mathrm{mg} \mathrm{chl} \mathrm{a} \mathrm{m}^{-2}$ ).

\section{Sediment rate measurements}

\section{Oxygen uptake}

There was a broad range of sedimentary oxygen uptake rates along the transect (Table 2), from $507 \mu \mathrm{mol} \mathrm{O} \mathrm{O}^{-2} \mathrm{~h}^{-1}$ at the furthest offshore Site 12 to $10056 \mu \mathrm{mol} \mathrm{O} \mathrm{O}^{-2} \mathrm{~h}^{-1}$ at the inner muddy Site 4 . The overall trend of mean rates is illustrated in Fig. $4 \mathrm{~A}$. ANOVA indicated significant inter-site variation for rates of oxygen uptake on each occasion ( $p \leq 0.05$ ). However, post hoc Tukey analysis showed very few significant $(\mathrm{p} \leq 0.05)$ inter-site differences from Sites 6 to 12 but a consistent peak in oxygen uptake at the inner muddy sites. ANOVA indicated significant seasonal differences in oxygen uptake rates at each site ( $p \leq 0.003$ ). However, the clearest seasonal trends (i.e. significant correlation with seasonal temperature) and highest rates of oxygen uptake were at the muddy sites, whilst lower and non-temperature-dependent oxygen uptake rates were recorded at the sandier sites (Fig. 5). There was a significant positive correlation $(p<0.001)$ between overall average rates of oxygen uptake and sedimentary organic $C$ content along the transect.

\section{Denitrification}

The calculated rates of coupled denitrification from the initial trial at the outer Sites 10 to 12 proved to be

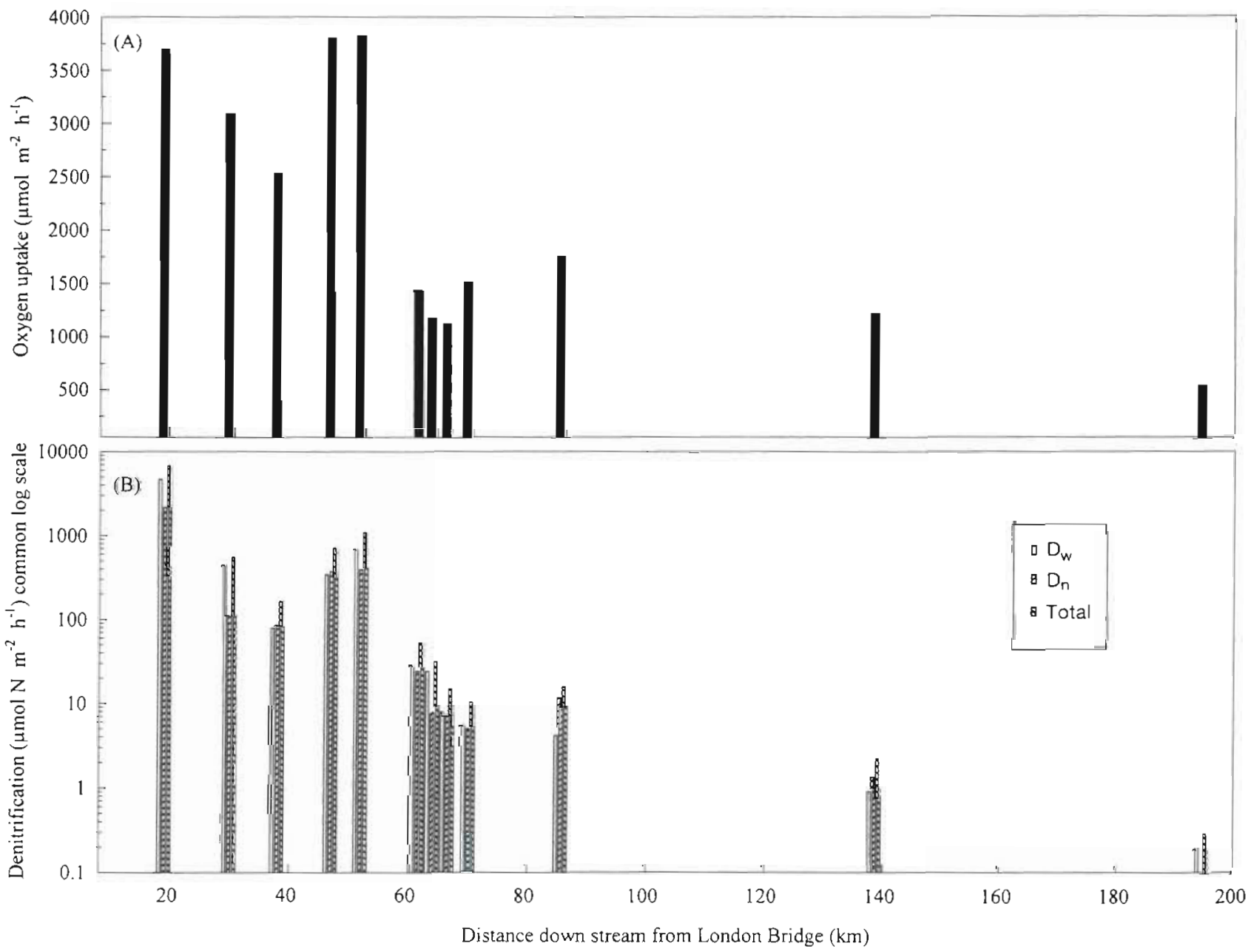

Fig. 4. Mean rates of (A) oxygen uptake and (B) denitrification at each site for all samples collected along the Thames transect 
Table 2. Sedimentary rates of oxygen uptake and denitrification ( $D_{\mathrm{w}}$ and $D_{\mathrm{n}}$ ) for each site in the Thames estuary, numbers in brackets are standard errors, $\mathrm{n}=3$ and 6 respectively. Note standard errors of $<1$ are not shown. All rates are $\mu$ mol $\mathrm{O}_{2}$ or $\mathrm{N} \mathrm{m}^{-2} \mathrm{~h}^{-1}$

\begin{tabular}{|c|c|c|c|c|c|c|c|c|c|c|c|c|c|}
\hline Site & Jul 96 & Aug 96 & Oct 96 & Nov 96 & Feb 97 & Mar 97 & Apr 97 & May 97 & Jun 97 Jul 97 & Aug 97 & Oct 97 & Jan 98 & Mar 98 \\
\hline \multicolumn{14}{|l|}{ Inner } \\
\hline $1 \mathrm{O}_{2}$ & & & & & & & $\begin{array}{l}2870 \\
(256)\end{array}$ & $\begin{array}{l}3562 \\
(142)\end{array}$ & $\begin{array}{c}7485 \\
(1037)\end{array}$ & $\begin{array}{l}3113 \\
(\mathbf{1 8 4})\end{array}$ & $\begin{array}{l}1740 \\
(578)\end{array}$ & $\begin{array}{l}2427 \\
(184)\end{array}$ & $\begin{array}{l}4721 \\
(449)\end{array}$ \\
\hline $1 D_{w}$ & & & & & & & $\begin{array}{l}11407 \\
(1259)\end{array}$ & $\begin{array}{l}2311 \\
(586)\end{array}$ & $\begin{array}{l}398 \\
(67)\end{array}$ & $\begin{array}{l}4389 \\
(296)\end{array}$ & $\begin{array}{l}2047 \\
(280)\end{array}$ & $\begin{array}{l}6626 \\
(855)\end{array}$ & $\begin{array}{l}5757 \\
(337)\end{array}$ \\
\hline $1 D_{\mathrm{n}}$ & & & & & & & $\begin{array}{l}8209 \\
(486)\end{array}$ & $\begin{array}{l}2428 \\
(293)\end{array}$ & $\begin{array}{l}558 \\
(89)\end{array}$ & $\begin{array}{l}437 \\
(98)\end{array}$ & $\begin{array}{l}138 \\
(57)\end{array}$ & $\begin{array}{c}301 \\
(144)\end{array}$ & $\begin{array}{l}2991 \\
(290)\end{array}$ \\
\hline $2 \mathrm{O}_{2}$ & & & & & & & $\begin{array}{l}2610 \\
(383)\end{array}$ & $\begin{array}{l}2495 \\
(318)\end{array}$ & $\begin{array}{c}6304 \\
(1205)\end{array}$ & $\begin{array}{l}2884 \\
(538)\end{array}$ & $\begin{array}{l}1391 \\
(405)\end{array}$ & $\begin{array}{l}3220 \\
(434)\end{array}$ & $\begin{array}{c}2792 \\
(20)\end{array}$ \\
\hline $2 D_{\mathrm{w}}$ & & & & & & & $\begin{array}{c}418 \\
(129)\end{array}$ & $\begin{array}{c}43 \\
(11)\end{array}$ & $\begin{array}{l}235 \\
(66)\end{array}$ & $\begin{array}{c}98 \\
(21)\end{array}$ & $\begin{array}{l}36 \\
(4)\end{array}$ & $\begin{array}{c}2240 \\
(1035)\end{array}$ & $\begin{array}{l}58 \\
(7)\end{array}$ \\
\hline $2 D_{\mathrm{n}}$ & & & & & & & $\begin{array}{c}385 \\
(114)\end{array}$ & $\begin{array}{l}15 \\
(4)\end{array}$ & 0 & $\begin{array}{l}38 \\
(7)\end{array}$ & $\begin{array}{l}16 \\
(5)\end{array}$ & $\begin{array}{c}271 \\
(108)\end{array}$ & $\begin{array}{l}63 \\
(5)\end{array}$ \\
\hline $3 \mathrm{O}_{2}$ & & & & & & & $\begin{array}{l}1671 \\
(360)\end{array}$ & $\begin{array}{l}2924 \\
(237)\end{array}$ & $\begin{array}{l}2957 \\
(830)\end{array}$ & $\begin{array}{l}5384 \\
(186)\end{array}$ & $\begin{array}{l}1632 \\
(389)\end{array}$ & $\begin{array}{l}1527 \\
(140)\end{array}$ & $\begin{array}{l}1647 \\
(82)\end{array}$ \\
\hline $3 D_{w}$ & & & & & & & $\begin{array}{l}156 \\
(46)\end{array}$ & $\begin{array}{l}30 \\
(7)\end{array}$ & $\begin{array}{c}80 \\
(10)\end{array}$ & $\begin{array}{c}93 \\
(24)\end{array}$ & $\begin{array}{c}74 \\
(17)\end{array}$ & $\begin{array}{l}39 \\
(5)\end{array}$ & $\begin{array}{c}85 \\
(10)\end{array}$ \\
\hline $3 D_{n}$ & & & & & & & $\begin{array}{l}157 \\
(32)\end{array}$ & $\begin{array}{l}21 \\
(6)\end{array}$ & $\begin{array}{l}145 \\
(57)\end{array}$ & $\begin{array}{l}47 \\
(9)\end{array}$ & $\begin{array}{l}19 \\
(6)\end{array}$ & $\begin{array}{l}100 \\
(38)\end{array}$ & $\begin{array}{l}116 \\
(14)\end{array}$ \\
\hline $4 \mathrm{O}_{2}$ & $\begin{array}{l}4313 \\
(283)\end{array}$ & $\begin{array}{c}6022 \\
(1439)\end{array}$ & & $\begin{array}{l}2387 \\
(101)\end{array}$ & $\begin{array}{l}1415 \\
(104)\end{array}$ & $\begin{array}{l}1546 \\
(221)\end{array}$ & $\begin{array}{l}2574 \\
(186)\end{array}$ & $\begin{array}{l}3714 \\
(511)\end{array}$ & $\begin{array}{c}6443 \\
(1307)\end{array}$ & $\begin{array}{l}5486 \\
(504)\end{array}$ & $\begin{array}{l}2736 \\
(121)\end{array}$ & $\begin{array}{l}4301 \\
(509)\end{array}$ & $\begin{array}{c}4789 \\
(1008)\end{array}$ \\
\hline $4 D_{w}$ & $\begin{array}{l}310 \\
(26)\end{array}$ & $\begin{array}{l}243 \\
(30)\end{array}$ & & $\begin{array}{l}183 \\
(63)\end{array}$ & $\begin{array}{l}333 \\
(20)\end{array}$ & $\begin{array}{l}1646 \\
(423)\end{array}$ & $\begin{array}{c}741 \\
(163)\end{array}$ & $\begin{array}{l}123 \\
(25)\end{array}$ & $\begin{array}{l}109 \\
(29)\end{array}$ & $\begin{array}{l}124 \\
(22)\end{array}$ & $\begin{array}{l}165 \\
(30)\end{array}$ & $\begin{array}{c}96 \\
(19)\end{array}$ & $\begin{array}{c}58 \\
(12)\end{array}$ \\
\hline $4 D_{n}$ & $\begin{array}{l}213 \\
(23)\end{array}$ & $\begin{array}{l}334 \\
(39)\end{array}$ & & $\begin{array}{l}173 \\
(39)\end{array}$ & $\begin{array}{l}227 \\
(37)\end{array}$ & $\begin{array}{l}1816 \\
(557)\end{array}$ & $\begin{array}{c}962 \\
(198)\end{array}$ & $\begin{array}{c}81 \\
(11)\end{array}$ & $\begin{array}{c}158 \\
35\end{array}$ & $\begin{array}{l}151 \\
(33)\end{array}$ & $\begin{array}{c}53 \\
(11)\end{array}$ & $\begin{array}{l}215 \\
(44)\end{array}$ & $\begin{array}{l}90 \\
19\end{array}$ \\
\hline $5 D_{\mathrm{n}}$ & $\begin{array}{l}4328 \\
(714)\end{array}$ & $\begin{array}{l}10056 \\
(1326)\end{array}$ & & $\begin{array}{l}1772 \\
(326)\end{array}$ & $\begin{array}{l}1489 \\
(273)\end{array}$ & $\begin{array}{l}1412 \\
(78)\end{array}$ & $\begin{array}{l}5358 \\
(727)\end{array}$ & $\begin{array}{l}2625 \\
\{140\}\end{array}$ & $\begin{array}{l}4379 \\
(914)\end{array}$ & & & & \\
\hline $5 \mathrm{O}_{2}$ & $\begin{array}{l}217 \\
(28)\end{array}$ & $\begin{array}{c}99 \\
(17)\end{array}$ & & $\begin{array}{l}48 \\
(6)\end{array}$ & $\begin{array}{c}193 \\
(119)\end{array}$ & $\begin{array}{c}569 \\
(285)\end{array}$ & $\begin{array}{l}3261 \\
(519)\end{array}$ & $\begin{array}{c}986 \\
(172)\end{array}$ & $\begin{array}{l}178 \\
(18)\end{array}$ & & & & \\
\hline $5 D_{\mathrm{w}}$ & $\begin{array}{l}238 \\
(12)\end{array}$ & $\begin{array}{l}264 \\
(41)\end{array}$ & & $\begin{array}{l}71 \\
(4)\end{array}$ & $\begin{array}{l}324 \\
137\end{array}$ & $\begin{array}{c}275 \\
(166)\end{array}$ & $\begin{array}{l}1513 \\
(440)\end{array}$ & $\begin{array}{l}187 \\
(36)\end{array}$ & $\begin{array}{c}284 \\
50\end{array}$ & & & & \\
\hline $6 \mathrm{O}_{2}$ & $\begin{array}{l}1798 \\
(255)\end{array}$ & $\begin{array}{l}836 \\
(74)\end{array}$ & & $\begin{array}{l}1006 \\
(127)\end{array}$ & $\begin{array}{c}502 \\
(182)\end{array}$ & $\begin{array}{c}500 \\
(1)\end{array}$ & $\begin{array}{c}955 \\
(197)\end{array}$ & $\begin{array}{l}2407 \\
(451)\end{array}$ & $\begin{array}{l}2220 \\
(428)\end{array}$ & $\begin{array}{l}3680 \\
(413)\end{array}$ & $\begin{array}{l}539 \\
(45)\end{array}$ & $\begin{array}{l}1502 \\
(70)\end{array}$ & $\begin{array}{l}1843 \\
(243)\end{array}$ \\
\hline $6 D_{w}$ & 35 & 7 & & 74 & 59 & 18 & 0 & 0 & 11 & 103 & 11 & 19 & 8 \\
\hline & (5) & (1) & & $(22)$ & $(20)$ & $(8)$ & & & (4) & $(9$ & (1) & (9) & $(1)$ \\
\hline $6 D_{\mathrm{n}}$ & $\begin{array}{l}45 \\
(6)\end{array}$ & $\begin{array}{l}15 \\
(4)\end{array}$ & & $\begin{array}{l}110 \\
(34)\end{array}$ & $\begin{array}{c}67 \\
(19)\end{array}$ & 0 & 0 & 0 & $\begin{array}{l}19 \\
(6)\end{array}$ & 0 & $\begin{array}{l}14 \\
(1)\end{array}$ & $\begin{array}{l}17 \\
(5)\end{array}$ & 8 \\
\hline $7 \mathrm{O}_{2}$ & $\begin{array}{l}1277 \\
(95)\end{array}$ & $\begin{array}{l}1636 \\
(393)\end{array}$ & & $\begin{array}{l}932 \\
(47)\end{array}$ & $\begin{array}{l}620 \\
(48)\end{array}$ & $\begin{array}{c}490 \\
(122)\end{array}$ & $\begin{array}{c}705 \\
(117)\end{array}$ & $\begin{array}{l}2147 \\
(485)\end{array}$ & $\begin{array}{c}823 \\
(453)\end{array}$ & & & & \\
\hline $7 D_{w}$ & $\begin{array}{c}35 \\
(1)\end{array}$ & $\begin{array}{c}54 \\
(11)\end{array}$ & & $\begin{array}{l}27 \\
(7)\end{array}$ & $\begin{array}{c}4 \\
(1)\end{array}$ & $\begin{array}{l}27 \\
(2)\end{array}$ & $\begin{array}{l}14 \\
(9)\end{array}$ & $\begin{array}{l}17 \\
(7)\end{array}$ & $\begin{array}{l}17 \\
(6)\end{array}$ & & & & \\
\hline $7 D_{n}$ & $\begin{array}{l}25 \\
(2)\end{array}$ & $\begin{array}{l}16 \\
(1)\end{array}$ & & $\begin{array}{l}22 \\
(3)\end{array}$ & 0 & 0 & 0 & 0 & 0 & & & & \\
\hline $8 \mathrm{O}_{2}$ & $\begin{array}{l}1358 \\
(266)\end{array}$ & $\begin{array}{c}1306 \\
(63)\end{array}$ & & $\begin{array}{l}566 \\
(80)\end{array}$ & $\begin{array}{c}558 \\
(207)\end{array}$ & $\begin{array}{l}535 \\
(23)\end{array}$ & $\begin{array}{c}697 \\
(175)\end{array}$ & $\begin{array}{c}672 \\
(101)\end{array}$ & $\begin{array}{l}1004 \\
(214)\end{array}$ & $\begin{array}{l}2500 \\
(161)\end{array}$ & $\begin{array}{l}1576 \\
(540)\end{array}$ & $\begin{array}{l}1136 \\
(85)\end{array}$ & $\begin{array}{l}1248 \\
(142)\end{array}$ \\
\hline $8 D_{w}$ & $\begin{array}{l}35 \\
(9)\end{array}$ & $\begin{array}{l}11 \\
(2)\end{array}$ & & 0 & 2 & 0 & $\begin{array}{c}3 \\
(2)\end{array}$ & $\begin{array}{c}7 \\
(1)\end{array}$ & $\begin{array}{l}15 \\
(2)\end{array}$ & $\begin{array}{l}14 \\
(3)\end{array}$ & $\begin{array}{c}5 \\
(2)\end{array}$ & 0 & $\begin{array}{c}4 \\
(1)\end{array}$ \\
\hline $8 D_{\mathrm{n}}$ & $\begin{array}{l}35 \\
(3)\end{array}$ & $\begin{array}{l}14 \\
(2)\end{array}$ & & 0 & $\begin{array}{c}5 \\
(1)\end{array}$ & 0 & 0 & $\begin{array}{l}11 \\
(1)\end{array}$ & 0 & $\begin{array}{l}10 \\
(3)\end{array}$ & $\begin{array}{c}9 \\
(1)\end{array}$ & 0 & $\begin{array}{c}4 \\
(1)\end{array}$ \\
\hline $9 \mathrm{O}_{2}$ & $\begin{array}{l}2242 \\
(552)\end{array}$ & $\begin{array}{l}3956 \\
(449)\end{array}$ & & $\begin{array}{l}553 \\
(59)\end{array}$ & $\begin{array}{c}898 \\
(125)\end{array}$ & $\begin{array}{l}410 \\
(32)\end{array}$ & $\begin{array}{c}689 \\
(250)\end{array}$ & $\begin{array}{l}1137 \\
(308)\end{array}$ & $\begin{array}{c}2264 \\
(1393)\end{array}$ & & & & \\
\hline $9 D_{w}$ & $\begin{array}{l}17 \\
(2)\end{array}$ & $\begin{array}{l}18 \\
(4)\end{array}$ & & 1 & 2 & 0 & 0 & 1 & $\begin{array}{c}6 \\
(1)\end{array}$ & & & & \\
\hline $9 D_{n}$ & $\begin{array}{l}16 \\
(4)\end{array}$ & $\begin{array}{l}12 \\
(3)\end{array}$ & & 1 & 1 & 0 & 0 & 0 & $\begin{array}{l}11 \\
(3)\end{array}$ & & & & \\
\hline
\end{tabular}


Table 2. (continued)

\begin{tabular}{|c|c|c|c|c|c|c|c|c|c|c|c|c|c|c|}
\hline Site & Jul 96 & Aug 96 & Oct 96 & Nov 96 & Feb 97 & Mar 97 & Apr 97 & May 97 & Jun 97 & Jul 97 & Aug 97 & Oct 97 & $\operatorname{Jan} 98$ & Mar 98 \\
\hline \multicolumn{15}{|l|}{ Outer } \\
\hline $10 \mathrm{O}_{2}$ & $\begin{array}{l}2325 \\
(425)\end{array}$ & & $\begin{array}{l}1383 \\
(252)\end{array}$ & & & & $\begin{array}{l}1058 \\
(58)\end{array}$ & & & $\begin{array}{l}2278 \\
(233)\end{array}$ & & & & \\
\hline $10 D_{w}$ & 5 & & $\begin{array}{c}5 \\
(1)\end{array}$ & & & & 3 & & & 4 & & & & \\
\hline $10 D_{\mathrm{n}}$ & $\begin{array}{l}27 \\
(2)\end{array}$ & & $\begin{array}{c}9 \\
(1)\end{array}$ & & & & $\begin{array}{c}5 \\
(1)\end{array}$ & & & $\begin{array}{c}7 \\
(1)\end{array}$ & & & & \\
\hline $11 \mathrm{O}_{2}$ & $\begin{array}{l}1481 \\
(129)\end{array}$ & & $\begin{array}{c}1480 \\
(27)\end{array}$ & & & & $\begin{array}{l}473 \\
(77)\end{array}$ & & & $\begin{array}{l}1458 \\
(368)\end{array}$ & & & & \\
\hline $11 D_{w}$ & 2 & & 1 & & & & 2 & & & 0 & & & & \\
\hline $11 D_{n}$ & 1.3 & & $\begin{array}{c}4 \\
(1)\end{array}$ & & & & 0 & & & 2 & & & & \\
\hline $12 \mathrm{O}_{2}$ & $\begin{array}{c}541 \\
(136)\end{array}$ & & $\begin{array}{l}609 \\
(35)\end{array}$ & & & & $\begin{array}{l}507 \\
(59)\end{array}$ & & & $\begin{array}{l}1427 \\
(127)\end{array}$ & & & & \\
\hline $12 D_{w}$ & 0 & & 0 & & & & 1 & & & 0 & & & & \\
\hline $12 D_{\mathrm{n}}$ & 0 & & 0 & & & & 0 & & & 0 & & & & \\
\hline
\end{tabular}

independent of the concentration of ${ }^{15} \mathrm{NO}_{3}{ }^{-}$added, which was taken as good evidence for a uniform mixing of the ${ }^{14} \mathrm{NO}_{3}{ }^{-}$and ${ }^{15} \mathrm{NO}_{3}{ }^{-}$isotope pools.

Denitrification, both that driven by nitrate from the overlying water $\left(D_{\mathrm{w}}\right)$ and that coupled to nitrification in the sediment $\left(D_{n}\right)$ (Table 2$)$, followed a trend along the transect similar to that of oxygen uptake, from negligible rates of approximately 0 to $1 \mu \mathrm{mol} \mathrm{N}$ $\mathrm{m}^{-2} \mathrm{~h}^{-1}$ for both $D_{\mathrm{w}}$ and $D_{\mathrm{n}}$ at the furthest offshore site, Site 12 , to maximum values of 11407 and $8209 \mu \mathrm{mol}$ $\mathrm{N} \mathrm{m}^{-2} \mathrm{~h}^{-1}$, respectively, at the inner muddy Site 1. The overall trend of mean values is illustrated in Fig. 4B. ANOVA indicated significant intersite variation for rates of $D_{\mathrm{w}}$ and $D_{\mathrm{r}}$ on each occasion ( $p \leq 0.038$ ), with significantly higher rates consistently being measured at the muddy sites. ANOVA indicated significant seasonal variation $(\mathrm{p} \leq 0.004)$ in the rates of $D_{\mathrm{w}}$ (except Site $3, \mathrm{p}=0.142$ ) and $D_{\mathrm{n}}$ (except Sites 3 and 7, p $=0.090$ and 0.105 , respectively) measured at each of the sites. The average rates of both $D_{\mathrm{w}}$ and $D_{\mathrm{n}}$ were significantly ( $\mathrm{p}<$ $0.05)$ positively correlated with the sediment organic $C$ content along the transect. There was a significant positive correlation $(\mathrm{p}<0.001)$ between the overall average rates of $D_{w}$ and overall average $\mathrm{NO}_{3}{ }^{-}$concentrations for all sites along the transect. However, this relationship was strongest $(r=0.92$ compared with $r=0.53)$ at Sites 6 to 12, with a sediment organic $C$ content of $<1.5 \%$ (dry wt). The $D_{w}$ fraction dominated denitrification at the majority of the inner sites, with a maximum

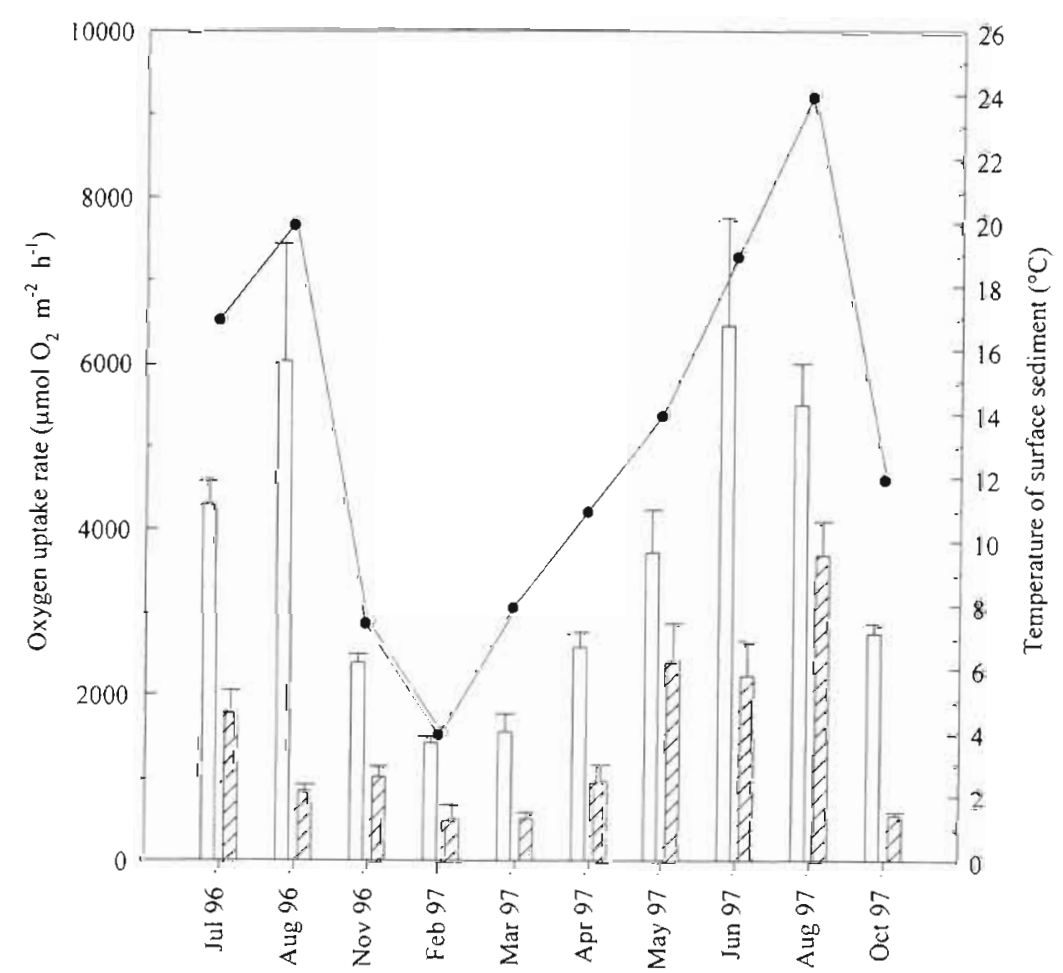

Fig. 5. Oxygen uptake rates at a muddy site (Site 4, open bars), and a sandy site (Site 6, hatched bars) together with the sediment temperature (•). Bars indicate standard error, $\mathrm{n}=3$ 
C delivered to the Thames estuary from either STW or fluvial discharge was deposited and remineralised before the mouth of the estuary at Southend. Zwolsmann (1994) also estimated that $60 \%$ of the fluvial sedinent discharge to the Thames estuary was retained within the estuary.

The average area-normalised rate of organic $\mathrm{C}$ mineralisation in the Thames estuary ( $21 \mathrm{~mol} \mathrm{C} \mathrm{m}{ }^{-2} \mathrm{yr}^{-1}$ ) was similar to that measured in the Great Ouse (29 mol $\mathrm{C} \mathrm{m}^{-2} \mathrm{yr}^{-1}$, Trimmer et al. 1998). Extrapolating the combined average area-normalised rate $\left(25 \mathrm{~mol} \mathrm{C} \mathrm{m}^{-2} \mathrm{yr}^{-1}\right)$ to the entire estuarine area of the UK $\left(6 \times 10^{9} \mathrm{~m}^{2}\right) \mathrm{sug}$ gests that $150 \mathrm{Gmol} \mathrm{C}\left(1.8 \times 10^{6} \mathrm{t}\right)$ is recycled back to the atmosphere each year. The annual estuarine production of $\mathrm{CO}_{2}$ in the UK is, therefore, comparable to that produced from agriculture, shipping, civil aircraft and railways, i.e. $1 \times 10^{6} t$ each, respectively (Digest of Environmental Statistics 1997). The recycling of fixed $\mathrm{C}$ back to atmospheric $\mathrm{CO}_{2}$ by estuarine sediments further emphasises the significance of estuaries as biological filters, not only of DIN loads but also of particulate and dissolved organic $\mathrm{C}$.

Acknowledgements. This work was part of the JoNuS (Joint Nutrient Study) programme funded by the Ministry of Agriculture, Fisheries and Food and the Department of the Environment, Transport and the Regions (both UK). The views expressed are those of the authors and do not reflect the policies of the funding departments. The authors wish to thank Dr Andrew Sage for compiling the nutrient load data and the Captain, Officers and crew of the RV 'Cirolina'.

\section{LITERATURE CITED}

Aller RC (1994) The sedimentary Mn cycle in Long Island Sound: its role as intermediate oxidant and the influence of bioturbation, $\mathrm{O}_{2}$, and $\mathrm{C}_{\text {org }}$ flux on diagenetic reaction balances. J Mar Res 52:259-295

Aller RC, Blair NE, Xia Q, Rude PD (1996) Remineralisation rates, recycling, and storage of carbon in the Amazon shelf sediments. Cont Shelf Res 16:753-786

Anderson FO, Helder W (1987) Comparison of oxygen microelectrodes, oxygen flux rate and electron transport system activity in coastal marine sediments. Mar Ecol Prog Ser 37: $259-264$

Billen G, Somville M, de Becker E, Servais P (1985) A nitrogen budget of the Scheldt hydrographical basin. Neth J Sea Res 19:223-230

Binnerup SJ, Jensen K, Revsbech NP, Jensen MH, Sørensen J (1992) Denitrification, dissimilatory reduction of nitrate to ammonium, and nitrification in a bioturbated estuarine sediment as measured with ${ }^{15} \mathrm{~N}$ and micro sensor techniques. Appl Environ Microbiol 58:303-313

Blackburn TH, Lund BA, Krom MD (1988) C- and N-mineralisation in the sediments of earthen marine fishponds. Mar Ecol Prog Ser 44:221-227

Cadée GC, Hedgman J (1974) Primary production of the benthic microflora living on tidal flats in the Dutch Wadden Sea. Neth J Sea Res 8:260-291

Caffrey JM, Sioth NP, Kaspar HF, Blackburn TH (1993) Effect of organic loading on nitrification and denitrification in a marine sediment microcosm. FEMS Microbiol Ecol 12: $159-167$

Cammen LM (1991) Annual bacterial production in relation to benthic microalgal production and sediment oxygen uptake in an intertidal sandflat and an intertidal mudflat. Mar Ecol Prog Ser 71:13-25

Cooper AB, Cooke JG (1984) Nitrate loss and transformation in 2 vegetated headwater streams. NZ $J$ Mar Freshw Res $18: 441-450$

Davidson NC, Laffoley Dd'A, Doody JP, Way LS, Gordon, J Key R, Drake CM, Pienkowski MW, Mitchell RM, Duff KL (1991) Nature conservation and estuaries in Great Britain. Nature Conservancy Council, Peterborough

de Jonge DJ, de Jonge VN (1995) Dynamics of microphytobenthos chlorophyll-a in the Scheldt estuary (SW Netherlands). Hydrobiologia 311:21-30

Digest of Environmental Statistics (1997) Department of the Environment, Transport and the Regions, Vol 19. The Stationery Office, London

Fielding PJ, Damstra KSJ, Branch GM (1988) Benthic diatom biomass, production and sediment chlorophyll in Langebaan Lagoon, South Africa. Estuar Coast Shelf Sci 27: 413-426

Hargrave BT, Philips GA (1981) Annual in situ carbon dioxide and oxygen flux across a subtidal marine sediment. Estuar Coast Shelf Sci 12:725-737

Heip CHR, Goosen NK, Herman PMJ, Kromkamp J, Middelburg JJ, Soetaert K (1995) Production and consumption of biological particles in temperate tidal estuaries. Oceanogr Mar Biol Annu Rev 33:1-149

Jørgensen BB (1982) Mineralisation of organic matter in the sea bed-the role of sulphate reduction. Nature 296: $643-645$

Jørgensen BB, Sørensen $\mathrm{J}$ (1985) Seasonal cycles of $\mathrm{O}_{2}, \mathrm{NO}_{3}{ }^{-}$ and $\mathrm{SO}_{4}{ }^{2-}$ reduction in estuarine sediments: the significance of an $\mathrm{NO}_{3}{ }^{-}$reduction maximum in spring. Mar Ecol Prog Ser 24:65-74

Jørgensen KS (1989) Annual pattern of denitrification and nitrate ammonification in estuarine sediment. Appl Environ Microbiol 55:1841-1847

Kelley CA, Martens CS, Chanton JP (1990) Variations in sedimentary carbon mineralisation rates in the White Oak River estuary, North Carolina. Limnol Oceanogr 35: $372-383$

Kirkwood DS (1992) Stability of solutions of nutrient salts during storage. Mar Chem 38:151-164

Kirkwood DS (1996) Nutrients: practical notes on their determination in seawater. Techniques in marine environmental science, No. 17. ICES, Copenhagen

Law CS, Rees AP, Owens NJP (1991) Temporal variability of denitrification in estuarine sediments. Estuar Coast Shelf Sci 33:37-56

Lohse L, Kloosterhuis R, van Raaphorst W, Helder W (1996) Denitrification rates in continental shelf sediments of the North Sea: acetylene block technique versus isotope pairing. Mar Ecol Prog Ser 132:169-179

Luther GW, Shellenbarger PA, Brendel PJ (1996) Dissolved organic $\mathrm{Fe}$ (III) and Fe (II) complexes in salt marsh porewaters. Geochim Cosmochim Acta 60:951-960

Mackin JE, Swider KT (1989) Organic matter decomposition pathways and oxygen consumption in coastal marine sediments. J Mar Res 47:681-716

Middelburg JJ, Klaver G, Nieuwenhuize J, Vlug T (1995) Carbon and nitrogen cycling in intertidal sediments near Doel, Scheldt Estuary. Hydrobiologia 311:57-69

Middelburg JJ, Klaver G, Nieuwenhuize J, Wielemaker A, de 
Haas W, Vlug T, van der Nat JFWA (1996) Organic mineralisation in intertidal sediments along an estuarine gradient. Mar Ecol Prog Ser 132:157-168

Mulder A, van de Graaf AA, Robertson LA, Kuenen JG (1995) Anaerobic ammonium oxidation discovered in a denitrifying fluidized bed reactor. FEMS Microbiol Ecol 16: $177-183$

Nedwell DB (1975) Inorganic nitrogen metabolism in a eutrophicated tropical mangrove estuary. Water Res 9: $221-231$

Nedwell DB, Trimmer M (1996) Nitrogen fluxes through the upper estuary of the Great Ouse, England: the role of the bottom sediments. Mar Ecol Prog Ser 142:273-286

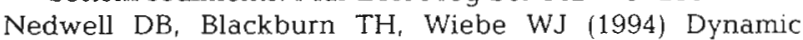
turnover of organic carbon, nitrogen and sulphur in the sediments of Jamaican mangrove forest. Mar Ecol Prog Ser 110:223-231

Nielsen K, Nielsen LP, Rasmussen P (1995) Estuarine nitrogen retention independently estimated by the denitrification rate and mass balance methods: a study of Norsminde Fjord, Denmark. Mar Ecol Prog Ser 119:275-283

Nielsen LP (1992) Denitrification in sediment determined from nitrogen isotope pairing. FEMS Microbio Ecol 86: $357-362$

Nielsen LP, Glud RN (1996) Denitrification in a coastal sediment measured in situ by the nitrogen isotope pairing technique applied to a benthic flux chamber. Mar Ecol Prog Ser 137:181-186

Nixon SW, Ammerman JW, Atkinson LP, Berounsky VM, Billen G, Boicourt WC, Boynton WR, Church TM, DiToro DM, Elmgren R, Garber JH, Giblin AE, Jahnke RA, Owens NJP, Pilson MEQ, Seitzinger SP (1996) The fate of nitrogen and phosphorus at the land-sea margin of the North Atlantic Ocean. Biogeochemistry 35:141-180

Nowicki BL, Requintina E, van Keuren D, Kelly JR (1997) Nitrogen losses through sediment denitrification in Boston Harbor and Massachusetts Bay. Estuaries 20:626-639

Ogilvie B, Nedwell DB, Harrison RM, Robinson A, Sage A (1997) High nitrate, muddy estuaries as nitrogen sinks: the nitrogen budget of the River Colne estuary (United Kingdom). Mar Ecol Prog Ser 150:217-228

Peieris B, Caraco N, Pace M, Cole J (1991) Human influence on river nitrogen. Nature 350:386-387

Reise K (1985) Tidal flat ecology: an experimental approach to species interactions. Springer Verlag, Berlin

Richards FA, Cline JD, Broenkow WW, Atkinson LP (1965) Some consequences of the decomposition of organic matter in Lake Nitinat, an anoxic fjord. Limnol Oceanogr (Suppl 10):R185-201

Rysgaard S, Christensen PB, Nielsen LP (1995) Seasonal vari-

Editorial responsibility: Otto Kinne (Editor), Oldendorf/Luhe, Germany ation in nitrification and denitrification in estuarine sediment colonised by benthic microalgae and bioturbating infauna. Mar Ecol Prog Ser 126:111-121

Sampou P, Oviatt CA (1991) Seasonal patterns of sedimentary carbon and anaerobic respiration along a simulated eutrophication gradient. Mar Ecol Prog Ser 72:271-282

Schlegel HG (1975) Mechanisms of chemoautotrophy. In: Kinne $O$ (ed) Marine ecology, Vol 2. John Wiley, London, p 9-60

Seitzinger SP (1988) Denitrification in freshwater and coastal marine ecosystems: ecological and geochemical significance. Limnol Oceanogr 35:702-724

Seitzinger SP (1990) Denitrification in aquatic sediments. In: Revsbech NP, Sørensen J (eds) Denitrification in soil and sediment. Plenum Press, New York, p 301-322

Seitzinger S, Nixon S, Pilson MEQ, Burke S (1980) Denitrification and $\mathrm{N}_{2} \mathrm{O}$ production in near-shore marine sediments. Geochim Cosmochim Acta 44:1853-1860

Sloth NP, Blackburn TH, Hansen LS, Risgarrd-Petersen N Lomstein BA (1995) Nitrogen cycling in sediments with different organic loading. Mar Ecol Prog Ser 116:163-170

Sørensen J, Jørgensen BB, Revsbech NP (1979) A comparison of oxygen, nitrate and sulphate respiration in coastal marine sediments. Microbial Ecol 5:105-115

Sørensen J, Rasmussen LK, Koike I (1987) Micromolar sulfide concentrations alleviate acetylene blockage of nitrous oxide reduction by denitrifying $P_{\text {seudomonas fluorescens. }}$ Can J Microbiol 33:1001-1005

Tait RV (1981) Elements of marine ecology, 3rd edn. Butterworths, London

Tett P (1987) Plankton. In: Baker JM, Wolff WM (eds) Biological surveys of estuaries and coasts. Cambridge University Press, Cambridge, p 280-341

Trimmer M, Nedwell DB, Sivyer D, Malcolm SJ (1998) Nitrogen fluxes through the lower estuary of the Great Ouse England: the role of the bottom sediments. Mar Ecol Prog Ser 163:109-124

Upton AC, Nedwell DB, Parkes RJ, Harvey SM (1993) Seasonal benthic microbial activity in the southern North Sea; oxygen uptake and sulphate reduction. Mar Ecol Prog Ser 101:273-281

Yoon WB, Benner R (1992) Denitrification and oxygen consumption in sediments of two south Texas estuaries. Mar Ecol Prog Ser 90:157-167

Zimmerman AR, Benner R (1994) Denitrification, nutrient regeneration and carbon mineralisation in sediments of Galveston Bay, Texas, USA. Mar Ecol Prog Ser 114: $275-288$

Zwolsmann JJG (1994) North Sea estuaries as filters for contaminants. Report T1233. Delft Hydraulics, Delft

Submitted: April 19, 1999; Accepted: November 23, 1999 Proofs received from author(s): April 14, 2000 